\title{
23. What is Holding them Back? Reflections on one Woman's Loss at the Polls: Usino-Bundi Open
}

\section{Laura Zimmer-Tamakoshi}

Women's struggles for equity continue to be frustrated in Papua New Guinea and other Pacific island nations (Dickerson-Putman and Zimmer-Tamakoshi 1994; Macintyre 1998). Issues such as gender violence are largely ignored by male politicians (Zimmer-Tamakoshi 1997d; Bradley 1998; Dinnen 2000; Human Rights Watch 2005) and everywhere women suffer political setbacks (Kidu 2006). In Papua New Guinea, only three women served in parliament concurrently in the decade following independence in 1975. From 1987 to 1997, there were no women in parliament and few in provincial offices. In 1997, two women were elected to the 109-member parliament, with one - the white widow of Sir Buri $\mathrm{Kidu}$ - staying on to represent one of the national capital electorates (Moresby South) for a second term. Lady Carol Kidu was recently re-elected for a third term, once again as the only female member of Papua New Guinea's national parliament.

As Papua New Guinea women bear many of the burdens of development, their virtual absence in politics is troubling. At a World Bank conference in Madang in 2006, it was noted that mining is not gender neutral and that women are rarely included in plans to encourage sustainable development or given equal access to justice, education, health care or economic resources. In surveys at the Ramu Nickel project in 1995 and 2000, I observed that men routinely left women out of genealogical data which might qualify the women as landowners. The same men expected their wives and unmarried sons and daughters to maintain newly made gardens and house sites in the sparsely populated rainforest while they - the husbands - were in town using land compensation monies to buy second wives and things of no benefit to those left behind (Zimmer-Tamakoshi 2001). In a keynote speech given at a dinner hosted by the Solomon Islands prime minister in Honiara, Lady Carol Kidu argued that, 'To waste half of the intellectual capacity of Melanesia by excluding women from our highest decision-making institutions is madness', calling for affirmative action to make Pacific parliaments more inclusive democratic institutions (Kidu 2006).

While proposals such as Lady Kidu's merit attention and it is evident that male dominance makes it difficult for female candidates, the question arises: why do not more women vote for female candidates? What congeries of factors 
and circumstances prevent women - who are capable actors in most realms of life - from becoming strong political actors both as 'women' and as Papua New Guinea citizens?

In 2006 I received word from a friend that she intended running for parliament in the 2007 national elections. A self-made businesswoman, actively engaged in promoting small-scale rural development and helping families (that is, both men and women), my friend seemed poised for victory over most other candidateswho promised big payouts from large-scale developments they had little control over and who reeked of corruption and indifference to gender issues. Returning to Papua New Guinea in 2007, I theorized that factors such as race, class and gender might play a decisive role in Betty's campaign and its ultimate success or failure. Previously, I had written that Papua New Guinea's male leaders helped marginalize the national women's movement (as well as mock women's aspirations in their own class) by promoting a myth opposing 'chaste and selfless' village women with 'promiscuous, Westernized' women living 'selfishly' in town with their rich white husbands or lovers (Zimmer-Tamakoshi 1993). I argued that in widening the gulf between rural and educated urban women and appealing to mass prejudice, leaders deflected attention from the interests of all women as well as their own weaknesses in representing their constituencies.

To understand better why women do not mobilize on common issues, I intended to explore further the politics of tradition and modernity as they relate to race, class and gender. In Melanesia, 'tradition' is associated with women and village mores while 'modernity' is associated more with men and Western-style business success and social endeavours (Zimmer-Tamakoshi 1995). In a seminal work on race and modernity, Bashkow (2006) shows how 'whiteness' is a moral concept signifying (for the Orokaiva at least) both success in modern terms and failure in maintaining traditional exchange relations. 'Whiteness' is now separable from white people and applicable to men of a certain class. While the Orokaiva have little to say on women and 'whiteness', my friend has been called 'white' and has suffered discrimination because of her white husband and unusual business success (Zimmer-Tamakoshi 1997c). Even so, in 2007 she felt sure it was the right time to run against men who lived in urban opulence and socialized more with Papua New Guinea's international elite. Unlike her opponents, Betty spends much of her time attending to her fish farm and tourist business on Mount Wilhelm as well as other rural activities and exchanges. I was interested to see both how she would set herself apart from the other candidates on key issues such as corruption, inequality, poor rural services and health care, and how various constituencies would perceive her framing of self. Would her opponents be perceived as more 'white' and less moral than she? Would women and young men see her as the embodiment of culture heroine Dobume (ZimmerTamakoshi 1997a, 1997b), who set Gende society on the right path by enabling 
her brother to marry and have children (something their mythical father had overlooked)? Would ordinary women who sacrifice to see that their children prosper (Zimmer-Tamakoshi 1996b; 1998) feel kinship with a woman who can easily afford better schools for her children and overseas trips? Either way, I expected my examination of the roles of race, class and gender in my friend's campaign would broaden discussion of race and modernity to include women and their political and economic situations. As it is, women are often left out of or lumped together in works on modernity and globalization (Knauft 1999). And understanding modernist dimensions of power and disempowerment is important to understanding the challenges Papua New Guinea women face.

\section{The candidate}

Betty Higgins was born in Goroka in 1958, the first child of 'houseboy' Ruge Angiva and his second wife Elizabeth. Born at a time when few migrants were accompanied by their wives and children, Betty started out life receiving much attention from her parents and those of her father's clan brothers who were part of their urban household. Often Betty's young uncles would babysit her while Betty's mother worked odd jobs for whites or gambled for money. Fluent in Pidgin, unafraid of white people and generous, Elizabeth was a focal point in the Goroka migrant community. She counselled others on the intricacies of keeping the white masters and their wives happy and used whatever earnings or handouts she received to support her husband's brothers when they arrived in town seeking their fortunes. Elizabeth was from the beginning an important role model for Betty.

When Betty was a toddler, Ruge brought her and his two pregnant wives back to his home village of Yandera to stay. With his own father near death, Ruge took over the running of his father's household. As the oldest male in his generation, Ruge received ample support from his father's younger brothers in the way of garden land and brideprice for a third wife. His uncles also paid off Elizabeth's brideprice as well as childwealth payments for Betty and her younger siblings. Investing heavily in their deceased brother's son, the uncles expected that when their own sons were of an age to marry, Ruge and his wives would be obligated to help them with brideprice pigs. Beyond that, they could also expect to receive portions of Ruge's daughters' brideprices. Being part of others' investment strategies, Betty was soon at the centre of their disputes. When Elizabeth enrolled Betty and her sister in the new boarding school at Bundi, it was against the protests of her uncles, who feared the consequences of two young girls living apart from their kin and developing any kind of 
independence. Ruge did not want to disagree with his uncles and so stood by while Elizabeth undertook the weekly trips to Bundi to take food to her girls and to help other parents plant gardens for the school's foreign teachers.

Although many students were homesick, Betty enjoyed her studies and the camaraderie of dorm life. When her mother left her father, Betty refused to go with her. Her only support during this time came from her maternal grandmother and several farseeing women who took pity on Betty. When it came time for Betty to transfer to a high school on the coast, her father refused to pay her airfare or school fees, urging her to stay home and work in the gardens to repay the debts her mother had walked out on (Gende women are expected to repay their brideprices). Again, it was women who put together the cash for Betty's airfare. When Betty and the other children arrived at Madang airport, the headmaster discovered that Betty did not have tuition money. He arranged for Betty to earn her own school fees doing some housekeeping for two teachers.

When Betty was not busy with schoolwork and chores, she enjoyed visiting the children's ward at the Madang hospital and giving fruit and flowers to the children who seemed most lonely. Betty was herself very lonely, feeling abandoned by her parents. On one of her hospital visits, Betty passed by the open room of a middle-aged white man. Although she was afraid, she was drawn into the room by the man's sad face. Putting flowers on his bedside table, she then fled without a word. The next time she visited the hospital, the head nurse took her to the man's room where Betty's beneficiary thanked her for cheering him up on what had been his birthday. The man gave Betty candy his wife and children had sent from Australia. Overcoming her shyness, Betty told the man her story and he decided to help her. Taking her to Australia during the summer holidays, he paid her tuition and gave her a regular book and clothing allowance throughout the remainder of her high school years. When the family returned to England on leave, Betty went with them.

After graduating from high school, Betty worked at several jobs before applying for a job at Air Niugini. With her good looks, intelligence, and charm, Betty enjoyed the heady life of an Air Niugini air hostess. Travelling between Port Moresby, other parts of Papua New Guinea and various Pacific capitals, Betty developed a sophistication few men and even fewer women possess. Shopping for bargains in Singapore and Hong Kong, enjoying the night life in Brisbane and Sydney, or caught up in the international whirl of Honolulu, Betty saw and did many things. Expected to wear makeup and dress fashionably, Betty attracted male attention. Though she dated Papua New Guineans, she preferred expatriates - feeling as many air hostesses and educated women did at the time (Zimmer-Tamakoshi 1993) - that Western men were kinder and more generous than their Papua New Guinean peers. 
Meeting her first husband on a flight from Australia, Betty moved out of the Air Niugini flats and into the spacious home of her Australian father-in-law, a car dealer in Port Moresby. Given the run of the house and a generous budget, she turned the house into a Mecca for other Gende who were in town for short visits or looking for work. Although her husband and father-in-law were unenthusiastic about the crowds of Gende who passed through their home, they were even less prepared to deal with Betty's parents. Not long after she started work for Air Niugini, Betty had brought about her parents' reunion. Once they realized her good fortune, Elizabeth and Ruge visited Port Moresby regularly and were a source of tension in Betty's marriage. They even demanded that their son-in-law and his father pay brideprice for Betty. Betty, however, preferred 'paying for herself' and 'being her own woman' and sent her parents back to the village.

Eventually a child was born and Betty named her Lisa, after the wife of a Chinese restaurant owner in Port Moresby. Close friends, the couple often took Lisa with them on trips to Hong Kong and Singapore. Since Betty continued working for Air Niugini, she arranged for her younger sisters to babysit Lisa. Soon, however, her mother moved back with her, claiming she could better look after Lisa. Another purpose was to make better use of Betty's prosperity. As Ruge many times described his and Elizabeth's relationship with their daughter, 'Betty is our business. We helped her grow up. We did many things for her. Now it is time to reap the profits'. Back in Yandera, Ruge directed departing migrants to Betty's house, calling it 'his home'. The irony of Ruge's expecting to control Betty's resources when he had contributed little to her education was not lost on Betty. She, however, chose to indulge him as long as he treated her mother fairly and because her father had become a very important bigman who could, if he wished, jeopardize Betty's plans to one day return home to the village to stay.

Meanwhile, disenchanted with her husband because of his substance abuse, Betty moved back to the Air Niugini flats. For several years she dated a succession of men. To her mother's disappointment, Betty refused the proposals of well-to-do Papua New Guineans in favour of another Australian, this time a man with several grown children from a previous marriage. An engineer at the Yonki dam site in Eastern Highlands Province, Ken was soon popular with his in-laws because of his generosity and his support of Betty's plans to return to Yandera to start a business and to raise her children away from the crime of Port Moresby. A dry-weather road had recently linked the Gende to urban markets in the Highlands and north coast. Investing her own and her husband's savings in a new pickup truck, a generator, freezer, and stereo and video equipment, Betty hoped to build a large coffee-buying business and other income-generating activities for herself and her relatives. Within a few months of her return in early 1986, Betty was buying coffee and transporting the beans 
to distant markets, selling beer and other alcoholic beverages in the village club she built, and charging villagers admission to weekend discos and video shows. Plans to sell vegetables to town markets did not materialize but Betty did open a well-stocked tradestore at one end of the five room log cabin she and her family lived in. With the generator she was able to keep and sell frozen meats along with a regular supply of fresh eggs from the chickens she penned up beneath her house.

For as long as they continued, Betty's business operations brought a measure of prosperity to Yandera village. Betty paid her father for the use of the land on which she built her home. She paid her father and other villagers K5000 for the materials and labour they put into building her house and the drinking club. Her mother ran the tradestore and kept most of the profits. Some two dozen women and children earned cash for carrying bags of coffee from Yandera to where the new road ended. And Betty hired two men as regular drivers and mechanics for the day-long trips to town. She made it easier than ever for villagers to sell their coffee. And there were more children enrolled in the local school as result of their being able to earn their own school fees doing small jobs for Betty.

The good times were soon over, however. Betty was giving out more than she was earning. She was, in fact, subsidizing village 'development' and getting nothing in return for her K30,000 investment. The causes of her failure were Betty's unfulfilled expectation that villagers would reciprocate her generosity and help build her business empire, and the Catholic mission's apparent opposition to any attempt to break their monopoly of business opportunities in the Gende area. Having to pay even close relatives to keep her supplied with such necessities as clean drinking water, Betty learned that villagers do not feel compelled to achieve a balance of exchange in their relations with more prosperous migrants. Village sentiment was summed up by one woman: 'When Betty and her husband stay in town they spend over K100 a night for a room in the Bird of Paradise Hotel. That is more money than most of us have in a year's time'. Competing with the mission, Betty paid villagers the same price per kilo of coffee even though she had the added cost of paying cartage to where her truck was parked (a charge villagers did not make against the more distant mission tradeposts). The foreign worker who did most of the coffee buying for the mission and was in charge of all government-funded work in the area, compounded Betty's difficulties by stopping work on the road into Yandera until after Betty had given up on her local business aspirations. A church catechist in Yandera was instrumental in closing down Betty's village pub.

After leaving Yandera, Betty and her husband purchased land on the slopes of Mount Wilhelm that is near enough to an all-weather road to make the sale of fresh vegetables, a vineyard, and other agricultural projects feasible moneymakers. By 1989 and 1990, Betty was supplying fresh vegetables to Anderson's 
Foodland stores in Lae and Rabaul and by 1994 she was raising trout and chickens as well as considering the possibility of raising rabbits for meat. The land was near enough to Gende territory that Betty's relatives could work for her and still maintain gardens and other village-based enterprises but far enough away that they did not control vital aspects of Betty's business operations such as land, labour, and road access. For several years Betty's father (until his death in 1991) and mother helped oversee her business while Betty divided her time between Yonki and the farm. By 1994 Betty and her family were living at the farm fulltime.

Still angered by the Catholic mission's lack of support for local entrepreneurs in her homeland, in 1989 Betty ran an unsuccessful political campaign for a seat in the Madang provincial government. As the first Gende woman to run for high office, Betty encountered prejudice from both men and women for acting 'like a man' and putting herself too much in the public eye. Nevertheless, many villagers considered her a serious candidate and those persons who had jeopardized her earlier coffee-buying business by their heavy demands now supported her election bid in the hope that she would bring more government funds and development projects to Yandera and other Gende villages. That she did not win was the result of the fragmentation that characterizes Papua New Guinea politics: people tending to vote for candidates who are related to them on the assumption that the winning candidates will reward wantok before passing on largesse to more distant associates. The most votes Betty received were from her own clan and village. She did, however, receive other votes and some were given precisely because she is a woman who is generous towards all Gende, regardless of kin affiliation and because she appears to be genuinely interested in promoting others' welfare. Far from giving up her political ambitions, Betty bided her time, building up both her business ventures (including a tourist lodge on her Mount Wilhelm property) and the trust and support of many persons. She continued to run her business operations in ways that benefitted many Gende and she has continued to be her own woman-beholden to no one and generous to all. And therein, ironically, may be one of the very reasons she suffered a second political loss in 2007.

\section{Her nomination and campaign}

I arrived in Papua New Guinea on 9 April 2007 for the first of two stints of fieldwork. In addition to wanting to observe Betty's campaign for Usino-Bundi Open, I had two other ongoing projects to attend to. At the start it was difficult to locate Betty. She had left a garbled message on my home phone while I was flying across the Pacific and now none of the contact numbers she had given me earlier was working. For several days I tried unsuccessfully to connect with her 
via her mobile phone, her email address, her second home at Mount Hagen, and the farm. On 12 April I received a hurried call from her saying all the phones up at the farm (and 'The Lodge') had been out for two months, that she could call out but no one could call in, that she was calling from Mount Hagen but on her way back to the farm, and that she would come down to Madang to get her mother and travel up to Yandera with me. I flew up to Madang the next morning. As it turned out she did not come down (some tourists showed up wanting to climb Mount Wilhelm) and I went up to Yandera to work on another project. Returning to Madang after a week, I waited for Betty's next call, knowing that the 'bush telegraph' would keep both Betty and me informed of one another's whereabouts. There were many Gende moving about because of the upcoming elections and I received almost daily news when I ran into them on the streets of Madang or they sought me out.

Betty's next call was on 25 April. Betty was now planning to walk down from Mount Wilhelm through the Gende homeland to the Ramu, where her son would meet her with her truck and they could then come into Madang to begin the nomination process. Her idea was to do some politicking along the way. The next day I ran into her mother, Elizabeth on the street on her way to 'find' me. For over a week, Elizabeth and I hung out together (and with other Gende), discussing the upcoming election, the candidates and their chances of winning (or not), and when exactly Betty would show up. Finally, we heard she was coming on Sunday, 6 May. Elizabeth rushed off to prepare a special meal for her but Betty didn't show up until late in the evening, too late for me to join the meal. The next morning, around 7:30 am, Betty and her entourage showed up at the house where I was staying. I had only a few minutes to throw my camera and a few other things in my backpack. Then we all crammed into her truck and drove around town getting money out of the bank for her nomination fee, buying phone cards for her mobile phone, shopping for supplies and sleeping bags for her campaign trail, picking up nomination paperwork, and all the time running into potential supporters. No matter how rushed we wereBetty intended driving up to Brahmin by nightfall to gather female supporters to go with us the next day to her nomination at the district headquarters in Walium - she stopped to discuss her platform. A number of listeners (including me) gave Betty cash contributions and Elizabeth bought a fancy bullhorn for her daughter.

At the bank we ran into Agatha Yama, who was planning to run for the Madang Open seat. I was talking with Agatha when a bank customer she knew walked up to her and gave her a check for K1000 saying he hoped she would win. Yama said her campaign was running on providence; that she had no money to live on and support her children as her husband had struck her name off their bank accounts. When we left the bank, Betty said the woman's husband 
was a bad man with several wives who was violent with Agatha. Both women were appealing to women on women's issues, but Betty said she was appealing less on issues of domestic violence than on the power of women as mothers and community members; women as faithful, caring, forgiving, concerned citizens who rarely drink and harm their families and who always think of their children's wellbeing.

As the day wore on, excitement mounted as different convoys of nominating candidates and their supporters drove through the streets and the crowds swelled. It seemed that everyone - or at least most of the men - had come down from the villages. Elizabeth began berating Betty for not giving cash handouts to the voters, saying that they would otherwise never vote for her. Betty, however, was intent on running a clean campaign, free of 'bribes' and 'corruption'. In the past, several important Gende politicians had made personal use of funds reserved by the big Ramu Nickel project for 'landowners', giving large sums of cash to those who supported them and failing to distribute the funds to other, legitimate 'landowners'. The misappropriated funds were said to be in the millions of kina. Betty preferred the more generalized and 'clean' hosting of small feasts to which everyone - men, women, and children — would be invited. Betty argued that giving bribes and relying on the wantok system was a thing of the past; that corruption started in the village because the people were poor and everyone wanted bribes for their votes. Clearly, her mother did not see eye to eye with her daughter and her hectoring continued.

While Elizabeth kept pushing the virtues of 'investing' in the voters so they might reciprocate with their votes, Betty received a phone call from Lae inviting her to attend the Agricultural Innovation Show and the 10th Celebration of the Papua New Guinea National Agricultural Research Institute (NARI) in two days' time. As a founding member of NARI, Betty's travel expenses were being covered and she was to pick up her ticket that day. As we rushed around with yet another set of tasks to accomplish I was reminded of how important Betty has been as both a role model for women in business and as an innovator (ZimmerTamakoshi 1996a). Betty was the first Papua New Guinean to farm-raise trout, at her Mount Wilhelm farm back in the mid 1990s, taking huge financial risks but travelling to Japan and other locations to learn about the process and to order her first fingerlings (baby trout). Betty's trout are sold in restaurants all over Papua New Guinea. Elizabeth was unimpressed, however, and kept haranguing her daughter until finally Betty ordered her out of the truck. As her mother walked away and we headed off to Brahmin, Betty remembered all her mother had done for her and her sisters, how she had basically raised them on her own and how her father had hurt her mother and his other wives so many times. We turned back to get Elizabeth and it was near dark when we finally arrived at the 'Pukpuk' bridge at the Ramu crossing. 
Along the way, there had been much talk among the truck's occupants-Betty, her son and mother, me, and several men and women who worked for her at the farm and who were going to assist her on her campaign trail. Several issues predominated: corruption, the virtues of female candidates, and the pros and cons of old and new ways. Throughout, the discussion was grounded in issues of race, class, and gender. Betty, a member of the educated elite, saw corruption as originating in villagers' poverty and misconceptions of how Western business worked. Others saw the corruption as pure greed and the trickery of educated Papua New Guineans who allegedly worked on their behalf but in fact made deals with outsiders and stole from their own kin. Betty's son, the product of privilege and his mother's marriage with a white Australian, argued that anyone who gave bribes for votes was stupid and that Papua New Guineans must follow the ways of the 'whites' who didn't allow sympathy or extortionist demands for bribes effect their choices and behaviour. Expanding upon the topic of corruption it was agreed by all in the truck that women are far more moral than men, putting their children and family above their own needs, and that they would never waste development funds on drinking and chasing the opposite sex. A male school teacher railed against old customs arguing that brideprice was a trap for women and villagers' constant feasting and demands for exchange payments for land rights and death and so much else were a drain on townsmen's limited resources. In the midst of all this talk, Elizabeth fell asleep muttering 'you must give them money' for their votes.

It was dusk when we arrived at the bridge and the gate was locked. Erected by the missionaries after floods had washed away part of the bridge, the gate prevented cars and trucks from crossing the bridge at night when it would be difficult to navigate what was left of the bridge. As no one was around to unlock the gate, two of Betty's party and myself hopped over the gate and walked to the mission several kilometres away. A man was sent back with the key and the rest of the group arrived at the mission, quickly dispersing to nearby houses to spend the night and prepare for the next day's nomination ceremony. In the morning, Betty set about renting several vehicles to help carry men and women to Walium. In the meantime, her son ferried people from the meeting spot at Brahmin to the Pukpuk bridge where we all waited for the convoy to begin. Once again the conversation turned to matters of race, class, and gender. Betty's son reiterated that 'white men think you are stupid if you vote for corrupt politicians'. Betty distanced herself from townsmen and male politicians by focusing on how she lived in a rural area and often visited her home village (' $m i$ meri bilong ples'), and that like all 'good women' she worked for the betterment of her family and community ('mi meri wok long famili').

When over a hundred supporters had gathered at the bridge, the convoy of three trucks took off for Walium. When we arrived, we all got out and waited 
near a store for others to join us. Women decorated themselves with leaves and flowers, painting their faces - some half white, half black-and talking among themselves about why they were supporting Betty. Their rhetoric centred on how it was their time now ('em taim bilong yumi') and how women concentrate on service and not self. Some of the younger women were made up to look more like men with beards, shouting 'mipela kam up man' ('we are men now'). When the group finally took off by foot to the district office with Betty in the lead, there was much singing and dancing by the women. When the procession came to a halt outside the district office, their refrain was picked up by Betty who repeated that she was a woman of the people, who lived off the land and whose only purpose was to work for her family and community, local development projects, education, better health and social services, and stronger families.

After another long wait, it was finally Betty's turn to sign the nomination papers. Only a few of us were allowed in to the office with Betty; the rest were glued to the open windows watching their candidate sign in. The moment was affecting. Having followed Betty's accomplishments for 25 years, I fumbled with my camera, my eyes misty (Betty, too, shed a tear). Elizabeth stood erect behind her daughter, dry-eyed but never more proud. On either side of Betty were a man and woman: the man a former local government counsellor and 'brother' of her deceased father; the woman one of the women who had long ago helped pay Betty's school fees.

\section{Her loss and its analysis}

After returning to Madang, Betty hurriedly bought some new shoes and clothes to wear to the NARI event and then rushed to catch a plane to Lae. Her son took the truck back to Mount Hagen and arranged to have election posters made up. Her mother and other Gende women, some visiting town for the nomination festivities, met to plan a big feast for Betty when she began her campaign in the villages. I continued with other research and then moved on to Port Moresby and Canberra before flying back to the United States at the end of May. I returned to Papua New Guinea in July and August to carry out a census and survey in Yandera village. Betty's mother Elizabeth assisted me and the other four members of my team (all from Papua New Guinea but none of Gende background) and I had daily opportunities to talk with Elizabeth and other villagers (and later, migrants in Madang and Port Moresby) about the outcome of the election. Betty herself was busy with work up at the farm and Lodge, and after an exhausting campaign walking from village to village in the mountainous terrain and then losing the election, disinclined to come down to the village to participate in the survey in person or to talk about the election. With over 200 families to survey I never found the time to go up to Mt Wilhelm 
myself. But in gathering her mother's testimony and that of other Gende (in addition to the testimony of some of her workers who came down to participate in the survey), I feel I have a solid enough perspective on the causes of her loss as well as what it meant to her and others in the wider Gende community.

When the Electoral Commission posted the election results as of 25 July, the winner of Usino-Bundi Open was Samson Kuli with 2535 first preference votes (11.9 percent) and 5263 votes (62.0 percent) after 34 counts. The runner-up was a distant second with only 1200 first preference votes (5.7 percent) and 3223 second and third preference votes (38.0 percent). Betty was excluded in the 14 th count with 371 first preference votes (1.8 percent). While she fell into the 23rd place in a race that ended up with 36 candidates pulling in first preference votes, Betty did hold her own against the only other female candidate, Margaret Yagum Sawi from Ramu Sugar who pulled in only 87 first preference votes (0.4 percent). Her brother-in-law and staunch competitor for Gende votes, David Duavu Tigavu, pulled in 944 votes (4.5 percent) and was not excluded until the 27th count, but Betty did beat fellow Gende and well-known writer Joe Koroma who received only 110 first preference votes and was excluded in the 9th count.

The election results generally produced a sense of gloom among the Gende. Peter Yama, the former Usino-Bundi member lost his race for the Madang Provincial seat to Sir Arnold Amet and was said by many Gende to be holing up in Australia and plotting revenge against those Gende who did not reciprocate his 'generosity' with votes. Some townsmen had fled back to their home villages and garden settlements for that very reason. Agatha Yama did not win the Madang Open. And David Tigavu, allegedly holding millions of kina for the Ramu Nickel landowners, did not win the Usino-Bundi seat. With no Gende in the national government, the Gende were in a weak position in any negotiations they might consider with the two big mineral resource projects (Ramu Nickel and Marengo Mining in Yandera) now in their midst. The most frequent comment about the election was that the Gende had wasted their votes by dividing them and voting for too many different candidates. Many voters were angry, with themselves and with the candidates. Candidates were accused of not combining their efforts to produce one or two strong candidates who might have stemmed the Ramu flood. Voters berated themselves as 'stupid' bush people who gave their votes away for a few kina or a piece of cooked pork. A number of men and women brought up the notion of forming two or three main parties rather than the many that now enter uneasy alliances in order to form a national government. Others felt that tribalism and the wantok system stood in the way of Papua New Guinea becoming more like Western nations. For her part, Betty's mother continued to complain about Betty wasting her money (and others' pigs) on small feasts instead of making direct cash handouts to voters. She excoriated those who had eaten at the feasts as 'ol $i$ kaikai nating' ('all ate 
without reciprocating') and bemoaned the rubbish customs of today's young people who allowed their children to stuff themselves at the feasts and then gave their votes to other candidates.

When I asked about Betty's campaign strategies and what people did or did not like about her as a potential member of parliament, no one expressed concern about the race of her husband or her mixed-race children. While race may have played a part in their judgements of Betty in the past (when she lived in Port Moresby), the facts that she and her family were committed to rural development and that Betty was a frequent visitor to the villages (unlike many educated migrants who have become soft and prefer their urban comforts) made her a true meri bilong ples in their eyes. Neither did people seem offended by her class - again, for the same reason: that she was willing to use her knowledge and extensive contacts to better the lives of local people. What did seem to matter was gender related. Some of those villagers who admitted they did not vote for her, and others who did, asserted that the primary reasons she lost were her lack of political experience and her failure to develop political ties with other politicians and local leaders. Most felt she was too individualistic in her style, focusing on her many accomplishments and intentions but lacking the networks of political influence necessary to be an effective leader whether traditionally or in the contemporary context of national politics. To be fair, many did admit that most other candidates had also run individual, divided campaigns. But Betty was a woman and women, according to some voters, do not cooperate well in political settings. More recently, in 2009, two of Betty's male political opponents - Anton Yagama (who came in second after the winner Samson Kuli) and her brother-in-law David Tigavu (who came in tenth) - and former UsinoBundi member Theo Tuya commented to me that Betty lost because politics is a 'man's world' and that she did not exhibit the necessary networking skills. This sentiment, while difficult to justify in light of Betty's business successes and her friendliness, was widely expressed to me by both men and women in the years since she lost the 2007 election.

\section{Conclusion: Women as political actors}

While the aforementioned comment would appear sexist, there may be a grain or two of truth in considering Papua New Guinean women as political actors in both traditional and contemporary settings. It is indeed true that long-term cowives often cooperate with one another to promote the polygynous household's overall political and social wellbeing as a means of also promoting their own and their natal families' interests (see Zimmer 1985; Zimmer-Tamakoshi 1997a). But virilocality (the most common post-marital residence in Papua New Guinea) and the absence of bonding, much less structured bonding, of women in female 
initiations (as opposed to male initiation practices) does not support groups of politically united women. There are well-known incidents of women coming together to fight for certain issues: the thousands of women who took to the streets in Port Moresby to protest the rape of an expatriate woman, and the Wok Meri movement in the Highlands, in which market women from different language groups created a network of' savings associations that allowed them to invest in various businesses but as importantly 'showed men' how they too should be investing their money (Sexton 1986). On a smaller scale, Gende women have in the past joined together to end a development that did not benefit their interests (Zimmer-Tamakoshi 1996b). While some individual Gende women have achieved great influence as a result of hard work and investments in others, few (except individuals like Betty and Elizabeth) dare stand up and speak to large crowds. Although there have been the exceptional women in parliament (Zimmer-Tamakoshi 1993), most Papua New Guinea women do not participate in overtly political groupings. Given this situation, proposals such as Lady Kidu's to affirmatively set aside a certain number of seats in parliament exclusively for women may be a necessary part of a more comprehensive plan to enable more women to learn the rules of the game and at the same time attend to the interests of half the population. Women would still have to run against one another for these seats and it is to be presumed that the more politically savvy would indeed win, thereby providing models and incentives for those coming up the ladder.

A different but related issue has to do with women's campaign rhetoric and goals. For the most part, Betty ran on a service platform, focusing on caring for family and community and small-scale developments. Few persons brought this up as a reason they didn't vote for Betty, but the few who did felt that it wasn't necessary to have a member in parliament to benefit from or invest in small-scale development but that it was necessary to maximize benefits from massive projects such as Ramu Nickel or to argue the need for road-building and extensive electrification projects. While Betty is admired for her business successes, her vocal indifference to the success or failure of Ramu Nickel and Marengo's nascent project alarms some men who are relying on the success of these two projects to provide them with the money needed to pay off the exchange debts they are incurring as they make multiple marriage and land deals with one another (Zimmer-Tamakoshi 2001, 2004, 2007). Also, many migrants are returning to the villages and rural areas to find work at these two large-scale developments. Given these broader interests of the voters, it would be wise if the affirmative action did not limit female politicians to so-called 'women's issues' and that both women and men be educated in the importance of all forms of development and services to every man, woman, and child in Papua New Guinea (Zimmer-Tamakoshi 2008). De-gendering the work of parliament at the same time as women are affirmatively brought into the fold will take a massive 
education program in how what happens to one part of a community directly affects for good or ill all the other parts. Should Papua New Guinea decide to take on such an innovative restructuring of its political system, it would stand above most other nations - certainly not an impossibility for a nation that has managed to survive quite a few challenges already. In the meantime, the Gende need to achieve a separate electorate from the Ramu half of the Usino-Bundi seat given that the two mining operations - if they continue to live up to their promise - will one day be providing major amounts of income to the national government and the Gende will deserve to see some of that income stream provide services that they greatly lack. This issue is one that Gende men and women are increasingly concerned about.

\section{References}

Bashkow, I., 2006. The Meaning of Whitemen: Race and Modernity in the Orokaiva Cultural World. Chicago: University of Chicago Press.

Bradley, C. 1998. 'Changing a "Bad Old Tradition" ', in L. Zimmer-Tamakoshi (ed.), Modern Papua New Guinea. Philadelphia: Thomas Jefferson University Press, pp. 351-364.

Dickerson-Putman, J. and Zimmer-Tamakoshi, L., 1994. 'Introduction', in J. Dickerson-Putman and L. Zimmer-Tamakoshi (eds), Women and Development in the Pacific, Special Issue of Urban Anthropology and Studies of Cultural Systems and World Economic Development 23(1):1-11.

Dinnen, S., 2000. 'Violence and governance in Melanesia: an introduction', in S. Dinnen and A. Ley (eds), Reflections on Violence in Melanesia. Canberra: Asia Pacific Press, pp. 172-177.

Human Rights Watch, 2005. 'Making Their Own Rules'. Police Beatings, Rape, and Torture of Children in Papua New Guinea. New York: Human Rights Watch.

Kidu, C., 2006. 'From patronage to partnerships'. Keynote speech, Honiara, reprinted in part in Pacific Magazine 2 June 2006.

Knauft, B., 1999. From Primitive to Postcolonial in Melanesia and Anthropology. Ann Arbor: The University of Michigan Press.

Macintyre, M., 1998. 'The persistence of inequality', in L. Zimmer-Tamakoshi (ed.), Modern Papua New Guinea. Philadelphia: Thomas Jefferson University Press, pp. 211-230. 
Sexton, L., 1986. Mothers of Money, Daughters of Coffee: The Wok Meri Movement. Ann Arbor: University of Michigan Press.

Zimmer, L., 1985. 'The Losing Game - Exchange, Migration, and Inequality Among the Gende People of Papua New Guinea'. PhD thesis, Bryn Mawr College.

Zimmer-Tamakoshi, L., 1993. 'Nationalism and sexuality in Papua New Guinea', Pacific Studies 16(4):20-48.

Zimmer-Tamakoshi, L., 1995. 'Passion, poetry, and cultural politics in the South Pacific', in R. Feinberg and L. Zimmer-Tamakoshi (eds), Politics of Culture in the Pacific Islands, Special Issue of Ethnology 34(2 and 3):113-127.

Zimmer-Tamakoshi, L., 1996a. 'Role models for contemporary Gende women', in H. Levine and A. Ploeg (eds), Work in Progress: Essays in New Guinea Highlands Ethnography in Honour of Paula Brown Glick. Frankfurt am Main: Peter Lang, pp. 317-341.

Zimmer-Tamakoshi, L., 1996b. 'The women at Kobum Spice Company. Tensions in a local age stratification system and the undermining of development', in J. Dickerson-Putman (ed.), Women, Age, and Power: The Politics of Age Difference Among Women in Papua New Guinea and Australia, Pacific Studies, pp. 71-98.

Zimmer-Tamakoshi, L., 1997a. 'Empowered women', in W. Donner and J. Flanagan (eds), Social Organization and Cultural Aesthetics: Essays in Honor of William H. Davenport. Philadelphia: University of Pennsylvania Press, pp. 45-60.

Zimmer-Tamakoshi, L., 1997b. 'Moga-Omoi's daughters', South Pacific Journal of Philosophy and Culture 2:1-20.

Zimmer-Tamakoshi, L., 1997c. 'The last big man: development and men's discontents in the Papua New Guinea highlands', Oceania 68(2):107-122.

Zimmer-Tamakoshi, L., 1997d. 'Wild pigs and dog men: rape and domestic violence as women's issues in Papua New Guinea', in C. Brettell and C. Sargent (eds), Gender in Cross-Cultural Perspective. Upper Saddle River: PrenticeHall, pp. 538-553.

Zimmer-Tamakoshi, L., 1998. 'Papua New Guinea women in town: housewives, homemakers, and household managers', in L. Zimmer-Tamakoshi (ed.), Modern Papua New Guinea. Philadelphia: Thomas Jefferson University Press, pp. 195-210. 
Zimmer-Tamakoshi, L., 2001. 'Development and ancestral gerrymandering: David Schneider in Papua New Guinea', in R. Feinberg and M. Ottenheimer (eds), The Cultural Analysis of Kinship: The Legacy of David Schneider and Its Implications for Anthropological Relativism. Chicago: University of Illinois Press, pp. 187-203.

Zimmer-Tamakoshi, L., 2004. 'Rape and other sexual aggression', in C. Ember and M. Ember (eds), The Encyclopedia of Sex and Gender. Dordrecht: Kluwer Academic Publishing, pp. 230-243.

Zimmer-Tamakoshi, L., 2007. 'Troubled masculinities and gender violence in Melanesia'. Paper presented at ASAO Working Session Engendering Violence in Oceania. Charlottesville.

Zimmer-Tamakoshi, L., 2008. 'It's not about women only', in L. ZimmerTamakoshi and J. Dickerson-Putman (eds), Pulling the Right Threads: The Ethnographic Life and Legacy of Jane C. Goodale. Chicago: University of Illinois Press.

Note to chapter: The full results for Usino-Bundi Open electorate were not available. Summary results can be found at the end of this book. 